\title{
STRATEGI KESANTUNAN TINDAK TUTUR DIREKTIF WERKUDARA DALAM WAYANG PURWA: ANALISIS POLA PROSODI
}

\author{
Eti Setiawati dan Titis Bayu Widagdo \\ Universitas Brawijaya \\ e-mail:ety64@ub.ac.id
}

\begin{abstract}
Abstrak
Tokoh Werkudara (WR) memiliki kekhasan yang menjadikan tokoh tersebut unik dan berbeda dibanding tokoh lainya dalam pementasan wayang purwa. Secara kebahasaan tokoh WR memiliki gaya berbicara kasar dan tidak pernah berbicara halus, dan cenderung tidak santun terhadap mitra tuturnya. Tujuan penelitian ini adalah mendeskripsikan pola prosodi strategi kesantunan tindak tutur direktif yang dilakukan tokoh Werkudara dalam wayang purwa. Penelitian ini menggunakan data tindak tutur direktif yang dilakukan tokoh Werkudara dalam lakon Dewa Ruci dengan pemilihan kalimat target tindak tutur direktif requestives sub fungsi meminta dengan struktur S-P-Pel aku jaluk pamit dan tindak tutur direktif questions sub fungsi bertanya dengan strutur apa-S?. Sumber penelitian yang digunakan dalam penelitian ini adalah rekaman video pementasan wayang lakon Dewa Ruci oleh Ki Nartosabdo. Data tuturan tersebut diproses dengan menggunakan aplikasi Praat dengan berpedoman pada aturan IPO(Instituut voor Perceptie Onderzoek) guna menggambarkan dan mempersepsikan aspek prosodi dari tuturan Werkudara kepada masing-masing mitratuturnya. Penelitian ini menggunakan teori pragmatik sebagai pisau bedah guna menjelaskan hubungan pola prosodi dalam membangun kesatunan dengan mitra tutur. Hasil penelitian ini dapat dijelaskan tiga pola prosodi dalam tindak tutur direktif Werkudara, yaitu pertama, konteks mitra tutur $(+D$, $+\mathrm{P}$ 'met') dalam tuturanya Werkudara menggunakan pola prosodi kontur nada turun atau deklinasi, julat nada tinggi (melodis), dan durasi panjang. Kedua konteks mitra tutur $(-\mathrm{D},+\mathrm{P}$ 'met') menggunakan pola prosodi kontur nada turun atau deklinasi, julat nada kecil (monoton), dan durasi panjang. Ketiga, konteks mitra tutur $(+\mathrm{D},+\mathrm{P}$ 'mat') menggunakan pola prosodi kontur nada naik atau inklinasi, julat nada kecil (monoton), dan durasi pendek.
\end{abstract}

Kata kunci: wayang purwa, werkudara, tindak tutur direktif, pola prosodi 


\title{
POLITENESS STRATEGY OF DIRECTIVE SPEECH ACT WERKUDARA IN THE WAYANG PURWA: PROSODIC ANALYSIS
}

\begin{abstract}
The Werkudara (WR) character has a peculiarity that makes this character unique and different from other characters in the shadow-puppet performances. Linguistically, the WR character has a harsh speaking style, never speaks softly, and tends to be disrespectful to his speech partners. The purpose of this study is to describe the prosody pattern of the directive speech acts of the politeness strategy performed by the Werkudara character in the puppet performance. This study uses the directive speech-act data performed by the character Werkudara in Dewa Ruci's play by selecting the target sentence directive speech-act requestives requesting sub-function with the structured target sentences S-P-Pel 'aku jaluk pamit' and the directive speech acts question subfunction of asking with the structure what-S?. The research source used in this study was the video recording of the Dewa Ruci puppet performance by Ki Nartosabdo. Furthermore, the speech data is processed using the Praat application guided by the IPO rules (Instituut voor Perceptie Onderzoek) to describe and perceive the prosody aspects of Werkudara's speech to each of his partners. This study uses the pragmatic theory as a tool to explain prosody patterns in building politeness with speech partners. The results of the study indicate the three prosody patterns in the speech acts of the Werkudara as follows. First, the context of the speech partners ( $+\mathrm{D},+\mathrm{P}$ 'met') in Werkudara's speech uses the prosody pattern of downward pitch or declination contours, high pitch range (melodic), and long duration. Second, the two contexts of speech partners (-D, $+\mathrm{P}$ 'met') use a downward or declination prosody pattern, a small pitch range (monotone), and a long duration. Third, the context of speech partners $(+\mathrm{D},+\mathrm{P}$ 'mat') uses a prosody pattern of rising or inclination contours, small pitch ranges (monotone), and short duration.
\end{abstract}

Keys word: shadow puppet, Werkudara, directive speech acts, prosody patterns.

\section{PENDAHULUAN}

Tokoh Werkudara (selanjutnya disingkat WR) merupakan tokoh yang populer dalam pementasan wayang purwa. Tokoh WR memiliki kekhasan yang menjadikan tokoh tersebut unik dan berbeda dibanding tokoh lainya dalam pementasan wayang purwa. Beberapa referensi telah menyimpulkan keunikan karakter dan keunikan kebahasaan dari tokoh WR, antara lain Poedjoesoedarmo
(1986), Nanda (2010), dan Sutardjo (2010) menjelaskan bahwa tokoh WR memiliki ciri khas yang unik dan berbeda dari tokoh lain, dari segi penyuaraan dan unda-usuk atau ragam bahasa.

Melengkapi penjelasan sebelumnya, Sena Wangi (1999) dan Sumari (2016) menjelaskan bahwa secara kebahasaan tokoh WR memiliki gaya berbicara kasar dan tidak pernah berbicara halus, dan cenderung tidak santun terhadap mitra 
tuturnya. Ciri khas WR tersebut juga dipertegas Lisbijanto (2013) yang menjelaskan bahwa tokoh WR mempunyai semboyan dalam hidupnya, yaitu dihadapanya semua orang sama derajatnya, sehingga dia tidak pernah menggunakan bahasa yang halus ketika bertutur di depan lawan bicaranya.

Beberapa pendapat di atas dapat disimpulkan bahwa tokoh WR merupakan tokoh yang unik. Keunikan tersebut dijelaskan dari sifat yang melekat pada tokoh WR antara lain, gaya bicara yang tidak pernah halus dan cenderung kurang santun dalam berinteraksi terhadap mitra tutur. Namun, sifat yang telah dipaparkan sebelumnya tersebut, terasa kontradiktif dengan analisis yang dilakukan peneliti. Dalam analisis data awal peneliti menemukan temuan baru bahwa tokoh WR memiliki strategistrategi kesantunan yang khas dalam interaksinya dengan mitra tutur.

Berdasarkan keunikan dan temuan peneliti tersebut maka dalam penelitian ini tindak tutur WR merupakan objek yang akan diteliti dalam penelitian ini. Sebagai penunjang data maka peneliti memilih pementasan wayang lakon Dewa Ruci oleh Ki Nartosabdo.

Lakon Dewa Ruci dipilih dalam penelitian ini karena dalam lakon tersebut WR merupakan tokoh sentral yang mendapat adegan yang dengan mitra tutur yang beragam. Hal tersebut membuat konteks tutur dan variasi prosodi WR lebih bervariasi.

Selain itu, Pemilihan Ki Nartosabdo sebagai pilihan dalang dalam penelitian ini juga bukan tanpa alasan. Pemilihan tersebut didasari dari fakta bahwa Ki Nartosabdo merupakan legenda dalang di Indonesia dengan pemahaman dan kemampuan yang sangat baik terkait catur pewayangan khususnya dalam hal penggambaran tokoh. Petersen \& Petersen, (2001) mengatakan "character voices, singing skill, and musical abilities were an important part of Nartosabdho's early popullarity, as his manipulation skills were still rudimentary. His oral/aural talents allowed him to capitalize on radio broadcast and the emerging market for cassete recordings". Kemampuan dari segi olah suara dan dialog merupakan salah satu hal paling menonjol dari sosok legenda Ki Nartosabdo.

Senada dengan pendapat sebelumnya Widodo (2017:39) menjelaskan bahwa sampai saat ini Ki Nartosabdo masih menjadi yang terdepan dalam menggambarkan karakter wayang dengan penguasaan bahasa Jawa, penyuaraan wayang, pemahaman bahasa Kawi, undha-usuk, purwakathi, maupun banyolan.

Selanjutnya, terkait pendalaman analisis peneliti menggunakan pisau bedah, yakni teori tindak tutur dan strategi kesantunan. Tindak tutur dalam pertunjukan wayang kulit merupakan unsur terpenting. Melalui tindak tutur tersebut akan dapat dicermati pengkarakteran setiap tokoh wayang. Dalam penelitian ini peneliti memfokuskan pada tindak tutur direktif (atau dalam penelitian ini disingkat TTD) WR. Menurut Searle (dalam Huang, 2007) dijelasakan bahwa TTD adalah tindak tutur yang mewakili usaha oleh penutur untuk menyuruh mitra penutur atau addrese melakukan sesuatu.

TTD menjadi fokus penelitian ini didasari bahwa TTD merupakan tindak 
tutur yang sangat bersinggungan dengan wajah penutur. Tujuan TTD tersebut berpeluang menciptakan persilisihan atau pemaksaan terhadap salah satu pihak dalam pertuturan. Untuk itu pemilihan tuturan yang santun dapat dijadikan alat guna menghindari pergesekan antara penutur dan mitra tutur. Hal tersebut selaras dengan filosofi orang Jawa yang dijelaskan oleh Geertz dalam (Suseno 1985) yang dijelaskan bahwa terdapat dua kalidah sosial yang menentukan bentuk dan pola pergaulan sosial pada masyarakat Jawa. Prinsip tersebut dijelaskan dalam dua bentuk, yaitu kerukunan dan penghormatan. Prinsip kerukunan mengacu pada kewajiban anggota masyarakat untuk memelihara keharmonisan, mengindari konflik. Sedangkan, prinsip penghormatan merupakan kewajiban bagi anggota masyarakat untuk menempatkan mitra tutur di tempat yang terhormat. Berdasarkan hal tersebut kesantunan merupakan salah satu upaya yang melekat pada setiap TTD yang utarakan oleh penutur.

Penelitian ini juga menggunakan analisis prosodi TTD WR. Unsur prosodi ini dijelaskan karena unsur prosodi memiliki peran penting dalam penggambaran kesantunan sebuah tuturan. Hal tersebut selaras dengan pendapat Culpaper (2003) menjelaskan bahwa "prosody plays a crucial role in the negotiation of (im)politeness. Prosodi atau suprasegmental dibangun dari berbagai unsur antara lain tinggi rendah bunyi (nada), keras lemah (tekanan), panjang pendek (tempo), dan kesenyapan (jeda) yang menyertai suatu tuturan. Menurut Chaer (2009) dan Culpeper (2011) dijelaskan secara terperinci unsur-unsur prosodi yang memiliki titik singgung dengan strategi kesantunan, antara lain sebagai berikut.

Pertama, nada dalam kajian prosodi berkenaan dengan tinggi rendahnya suatu bunyi (Chaer, 2009). Dalam variasinya nada dapat dijelaskan dengan hubunganya dengan frekuensi. Jika frekuensi getaran tinggi maka nada yang dihasilkan adalah nada tinggi, dan sebaliknya. Variasi nada tersebut dapat dipakai sebagai pembeda pada tataran kata maupun pada tataran kalimat. Pada tataran kata variasi nada disebut sebagai tona, sedangkan pada tataran kalimat variasi nada disebut sebagai intonasi.

Kedua, durasi adalah panjang pendeknya suatu bunyi yang diujarkan. Culpeper (2011) menjelaskan bahwa durasi dapat menjadi parameter panjang pendeknya suatu ujaran mulai dari tataran silabe, kata, sampai kalimat.

Ketiga, intonasi tidak mengubah arti leksikal, tetapi intonasi dapat menjelaskan maksud atau sikap penutur. Intonasi juga memilki pesan semantik. Dengan cara berfokus pada kontur intonasi, seorang pendengar dapat mengidentifikasi apakah pesan yang didengarnya. Fungsi intonasi dalam tuturan untuk membawa makna pragmatis pada tataran kalimat atau tataran postleksikal dalam bentuk yang terstruktur secara linguistik (Sugiyono, 2007).

Penetian terkait kesantunan untuk menunjang penelitian ini, pertama adalah penelitian dari Manaf (2011) dengan judul Kesopanan Tindak Tutur Menyuruh dalam Bahasa Indonesia. Berdasarkan penelitian yang telah dilakukan dapat disimpulkan ada dua 
cara utama yang dilakukan oleh penutur bahasa Indonesia untuk membentuk tindak tutur direktif yang santun, yaitu (1) menyuruh dengan basa-basi pengakraban dan penganjungan, (2) menyuruh dengan basa-basi peminimalan paksaan dan beban. Selanjutnya, penelitian dari Heriyawati dkk (2019) yang berjudul Lecturers' Politeness Strategies in Efl Classroom with Multicultural Background. Hasil dari penelitian ini dapat disimpulkan proporsi tertinggi dari strategi kesopanan yang diterapkan oleh dosen adalah kesopanan positif, strategi off-record, pernyataan langsung, dan kesopanan negatif. Hal ini menyiratkan bahwa sebagian besar dosen menerapkan kesopanan positif dalam mengkritik mahasiswa siswa, hal ini dilakukan untuk menghindari perasaan tersinggung, bias lebih akrab, dan memberikan umpan balik yang lebih positif untuk membantu mahasiswa mengembangkan kemampuan mengajar.

Penelitian-penelitian di atas secara umum menjelaskan aspek kesantunan berdasarkan penggunaan bahasa. $\mathrm{Hal}$ tersebut dirasa kurang maksimal karena salah satu aspek penting, yaitu prosodi luput dari analisis strategi kesantunan. Hal tersebut selaras dengan pendapat Culpaper (2003) the vast bulk of research on politeness or impoliteness pays woefully little attention to the role of prosody. Dalam beberapa kajian yang berkembang unsur prosodi seperti di anak tirikan. Padahal menurut Rahardi (1999) dalam penelitiannya dijelaskan empat pemarkah kesantunan linguistik (linguistik politeness) yang mempengaruhi kadar kesantunan dalam tuturan imperatif dalam bahasa Indonesia. Keempat pemarkah tersebut adalah 1) panjang pendek tuturan, 2) urutan tutur, 3) intonasi dan isyarat kinesik, dan 4) ungkapan-ungkapan penanda kesantunan, antara lain tolong, mohon, silahkan, mari, biar, ayo, dan lainlain.

Selanjutnya, Culpeper (2011), menguatkan pendapat sebelumnya dengan penelitiannya yang berjudul "'It's not what you said, it's how you said it!': Prosody and impoliteness" dalam dikusi ini dijelaskan hubungan antara kesantunan dan prosodi. Hubungan tersebut dapat meningkatkan kesadaran akan peran penting prosodi dalam kesopanan/ ketidaksopanan. Adapun dalam penelitian ini juga dipaparkan faktor prosodi yang mempengaruhi kesantunan, antara lain intonasi, nada, dan durasi.

Penelitian lebih konkret lagi terkait hubungan prosodi dan kesantunan juga dijelaskan oleh Rahyono (2009) dan Nadeu (2014). Pertama dalam penelitian Rahyono (2009) yang berjudul The Politeness Prosody of the Javanese Directive Speech dijelaskan hubungan durasi dan alir nada dalam memengaruhi kesantunan dalam tindak tutur direktif. Kesimpulan dalam penelitian ini adalah alir intonasi turun dan durasi yang panjang dalam tindak tutur direktif dipresepsikan merupakan tuturan yang lebih satun oleh masyarakat Jawa. Selanjutnya penelitian kedua adalah penelitian yang dilakukan oleh Nadeu (2014). Dalam penelitannya berjudul "Pitch range, gestural information, and perceived politeness in Catalan". Hasil analisis dari penelitian ini dapat dijelaskan hubungan antara unsur prosodi dan gestur berpengaruh pada kesantunan. Dalam percobaanya 
peningkatan julatnada bagian akhir dari nada ucapan menghasilkan penurunan kesopanan yang dirasakan, sedangkan penurunan julat nada tidak berpengaruh. Percobaan persepsi kedua menunjukkan bahwa menambahkan informasi kontekstual (gestural) membalikkan kecenderungan. Secara bersama-sama, hasil ini menunjukkan interaksi yang kompleks antara isyarat prosodik dan informasi kontekstual (khususnya, gerakan wajah).

Berdasarkan konsep teori dan penelitian terdahulu tersebut, peneliti dalam penelitian ini akan menjelaskan analisis berbeda dengan analisis pola prosodi WR dalam wayang purwa yang berimplikasi pada pola strategi kesantunannya. Kalimat target yang digunakan peneliti dalam mempolakan TTD WR, yaitu yaitu TTD requestives sub fungsi meminta dengan kalimat target berstruktur S-P-Pel aku jaluk pamit dan TTD questions sub fungsi bertanya dengan strutur apa-S? Penentunan dua TTD dan kalimat target didasari dua pokok alasan, yaitu pertama TTD requestives subfungsi meminta dan TTD questions subfungsi bertanya merupakan TTD yang paling dominan dituturkan WR ke setiap mitra tuturnya dalam lakon Dewa Ruci.

Selanjutnya, Dasar pola prosodi tersebut diklasifikasikan berdasarkan konteks mitra tutur. Menurut Brown \& Gilman (1960) konsep mitra tutur adalah keterikatan antara penutur dan mitra tutur dalam komunikasi dengan teori semantik solidarity dan power. Konteks mitra tutur berdasarkan konsep solidarity 'kedekatan' berhubungan dengan kedekatan antara penutur dan mitra tutur yang disimbolkan dengan (D). Terkait kekuasaan atau power antara penutur dan mitra tutur disimbolkan dengan (P). Adapun konteks kuasa penutur dan mitra tutur menurut Brown \& Levinson, (1983) dijelaskan terbagi menjadi dua kuasa, yaitu materil atau 'mat' merupakan kuasa bersifat materil seperti kekayaan, status sosial, pangkat. Sedangkan, metafisika atau 'met' merupakan kuasa yang berwujud sebuah jasa, ilmu, kesaktian, dan derajat.

Berdasarkan penjelasan di atas, penelitian ini akan memaparkan dua hal, yaitu bagaimana pola prosodi WR kepada mitra tuturnya dalam lakon Dewa ruci? dan bagaimana strategi kesantunan WR berdasakan pola prosodi yang digunakan WR dalam bertutur dengan mitra tuturnya dalam lakon Dewa Ruci?

\section{METODE}

Penelitian ini merupakan penelitian deskriptif kualitatif. Penelitian deskriptif kualitatif merupakan jenis penelitian yang menggali informasi terhadap objek kajian dengan mendeskripsikan semua sistem tanda yang dapat memberikan pemahaman yang lebih mendalam. Sistem tanda yang dimaksud adalah tuturan WR dalam sebuah pementasan wayang purwa. Dalam pendeskripsian tanda tersebut peneliti menggunakan aplikasi Praat guna menjabarkan aspekaspek prosodi dalam tuturan direktif WR dalam pementasaanya.

Data penelitian ini diperoleh dari tuturan direktif yang dituturkan WR dalam pementasan wayang purwa. Sumber data yang dipilih peneliti adalah rekaman wayang dengan lakon Dewa Ruci 
oleh Ki Nartosabdo. Adapun teknik analisis menggunakan Praat peneliti menggunakan ancangan analisis IPO (Instituut voor Perceptie Onderzoek). IPO merupakan ancangan yang didesain untuk mendeskripsikan sinyal akustik tuturan (Gussenhoven, Hart, Collier, Cohen, \& Collier, 1992).

Ancangan dalam penelitian fonetik menurut IPO dilakukan dalam tiga tahap, yaitu 1) penentuan kalimat target, 2) analisis akustis dengan penggunaan aplikasi Praat, dan 3) analisis presepsi dari pola prosodi.

Tahap pertama yang dilakukan peneliti dalam penelitian ini adalah mencari kalimat target. Berdasarkan tujuan untuk melihat pola fonetik WR maka peneliti dituntut mencari kalimat yang sama yang dituturkan kepada setiap mitra tuturnya. Kalimat target yang sama tersebut bertujuan untuk memberi gambaran secara detil terhadap perbedaan pola tuturan WR dalam bertutur dengan mitratuturnya. Adapun kalimat target yang ditentukan peneliti adalah TTD requestives sub fungsi meminta dengan kalimat target berstruktur S-P-Pel aku jaluk pamit dan TTD questions sub fungsi bertanya dengan strutur apa-S?.

Tahap kedua adalah tahap analisis akustis. Kalimat target yang telah ditentukan tersebut diolah dengan menggunakan aplikasi Praat guna mendapatkan gambaran dari prosodi tuturannya. Dalam penelitian ini peneliti memfokuskan terhadap tiga faktor prosodi, yaitu alur nada, julat nada, dan durasi tuturan. Tahap terakhir adalah tahap presepsi. Pola prosodi yang telah ditemukan delanjutnya dipresepsikan dengan teori kesantunan. Tahap ini akan menjelaskan pengaruh pola prosodi terhadap strategi kesantunan WR dalam bertutur dengan mitra tuturnya.

Selanjutnya, hasil analisis dijabarkan dengan bentuk deskriptif, yaitu dengan menggunakan bahasa atau kata-kata biasa yang sifatnya sangat teknis (Sudaryanto, 1993).

\section{HASIL DAN PEMBAHASAN \\ Hasil}

Penggambaran pola TTD WR peneliti menentukan dua kalimat target TTD yang akan dipolakan, yaitu TTD requestives sub fungsi meminta dengan kalimat target berstruktur S-P-Pel aku jaluk pamit dan TTD questions sub fungsi bertanya dengan strutur apa-S?. Penentunan dua TTD dan kalimat target didasari dua pokok alasan, yaitu pertama TTD requestives subfungsi meminta dan TTD questions subfungsi bertanya merupakan TTD yang paling dominan dituturkan WR ke setiap mitra tuturnya dalam lakon Dewa Ruci.

\section{Pola Prosodi TTD Requestives Sub Fungsi Meminta Kalimat 'aku jaluk pamit'}

Pola prosodi pertama yang dianalisis dalam penelitian ini adalah pola prosodi TTD Requestives subfungsi meminta WR dalam lakon Dewa Ruci. Kalimat tuturan yang menjadi target analisis ini adalah tuturan aku jaluk pamit. Tuturan WR tersebut dalam lakon Dewa Ruci dituturkan WR dengan berbagai mitra tutur, yaitu Durna, Dewa Indra, Dewi Kunti, dan Duryudana. 


\section{Pola Prosodi 'aku jaluk pamit' WR dengan Durna}

Secara konteks mitra tutur Durna dalam cerita Dewa Ruci ini digambarkan sebagai sosok guru besar negara Ngastina yang memberi pelajaran terkait ilmu persenjataan dan peperangan bagi anakanak Kurawa dan Pandawa, salah satu muridnya adalah WR. Durna merupakan tokoh yang dekat dengan WR dan juga sangat dihormati oleh tokoh WR. Secara konteks mitra tutur dapat di jelaskan dalam simbol (-D, $+\mathrm{P}$ 'met'). Tuturan TTD ini diutarakan oleh WR ketika meminta restu untuk mencari TPMS. Gambaran pola prosodi disajikan pada Tabel 1.

Tabel (1) menjelaskan pola prosodi tuturan aku jaluk pamit yang dituturkan
WR kepada Durna. Nada dasar pada tuturan di atas adalah $84,4 \mathrm{~Hz}$. Nada final dari kontur intonasi di atas adalah $78 \mathrm{~Hz}$. Nada puncak pada tuturan di atas adalah 86,8 Hz, sedangkan nada terendahnya berada pada titik $77,8 \mathrm{~Hz}$. Julat nada yang dihasilkan pada tuturan di atas adalah $9 \mathrm{~Hz}$.

Berdasarkan pola nada tuturan aku jaluk pamit maka dapat dijelaskan bahwa tuturan WR kepada Durna tersebut memiliki kontur nada turun atau deklinasi. Kontur tersebut dijelaskan berdasarkan terjadinya penurunan nada final dari tuturan tersebut, yakni dari mulanya nada awal berada pada titik 84,4 $\mathrm{Hz}$ turun menjadi $78,7 \mathrm{~Hz}$ pada nada final. berikut gambaran kontur nada yang dihasilkan WR dalam tuturan aku jaluk pamit kepada guru Durna.

Tabel 1 Pola Prosodi TTD Requestives sub fungsi meminta 'aku jaluk pamit' WR dengan Durna

\begin{tabular}{lllllll}
\hline Mitra tutur & Nada awal & Nada tertinggi & Nada terendah & Nada akhir & Julat nada & Durasi \\
\hline Durna & $84,4 \mathrm{~Hz}$ & $86,8 \mathrm{~Hz}$ & $77,8 \mathrm{~Hz}$ & $78 \mathrm{~Hz}$ & $9 \mathrm{~Hz}$ & $1088 \mathrm{~ms}$ \\
\hline
\end{tabular}

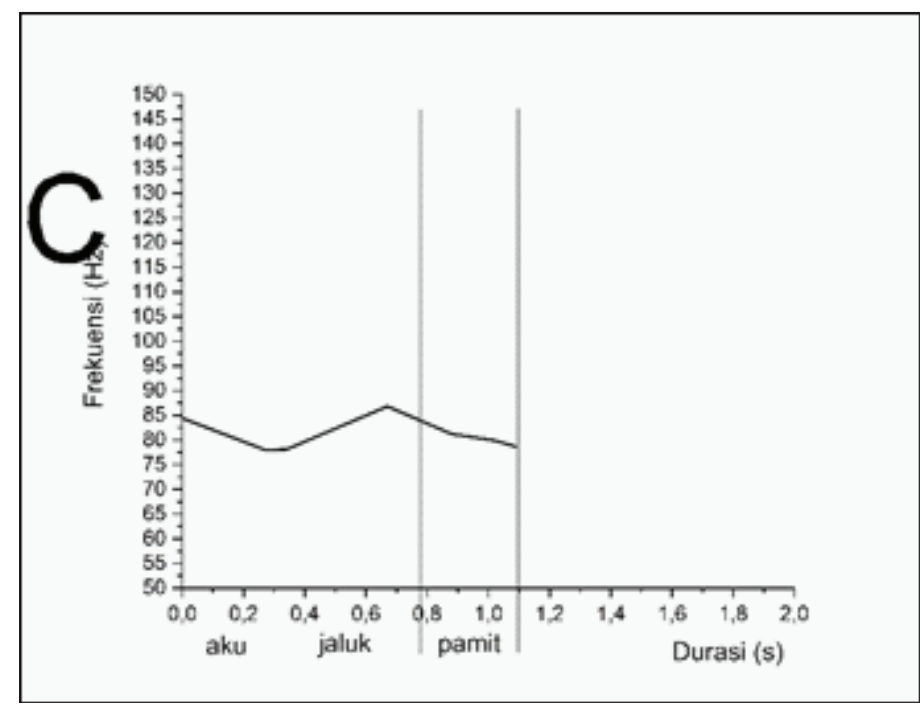

Gambar 1 Kontur Nada Tuturan 'aku jaluk pamit' WR kepada Durna 
Gambar (1) menunjukan alir nada pada tuturan aku jaluk pamit yang dituturkan WR kepada Durna. Alir nada turun ditunjukan pada subjek. selanjutnya alir nada turun naik dijelaskan dalam tataran predikat dan alir nada turun dijelaskan pada tataran pelengkap. Secara umum dapat dijelaskan kontur nada yang digunakan WR dalam tuturan aku jaluk pamit dengan guru Durna yang memiliki konteks mitra tutur $(-\mathrm{D},+\mathrm{P}$ 'met') adalah kontur nada turun atau deklinasi. Adapun pada tuturan aku jaluk pamit dengan Durna di atas juga dijelaskan durasi WR dalam menuturkan kalimat target tersebut dengan durasi $1088 \mathrm{~ms}$.

\section{Pola Prosodi 'aku jaluk pamit' WR dengan Dewa Indra}

Tuturan TTD aku jaluk pamit dituturkan WR kepada Dewa Indra ketika interaksi tersebut terjadi di alas Tebrosoroh. Dewa Indra dalam lakon ini diceritakan sebagai dewa yang diselamatkan WR dari kutukan menjadi raksasa karena kesalahan yang telah dilakukan. Secara kontektual Dewa Indra memiliki derajat yang lebih tinggi daripada WR. Dewa Indra dijelaskan juga memiliki kuasa yang besar atas kehidupan titah manusia. Sehingga dapat dijelaskan bahwa Dewa Indra memiliki derajat lebih tinggi serta memiliki kuasa metafisika yang diakui oleh WR, hal tersebut disimbolkan ( $+\mathrm{D},+\mathrm{P}$ 'met'). Tuturan TTD requestives sub fungsi meminta ini diutarakan oleh WR ketika meminta restu untuk mencari TPMS. Gambaran pola prosodi disajikan pada Tabel 2.

Tabel (2) menjelaskan pola prosodi dari tuturan aku jaluk pamit WR kepada Dewa Indra. Tuturan tersebut memiliki nada dasar 120,1 Hz. Nada final dari kontur intonasi di atas turun menjadi $89,5 \mathrm{~Hz}$. Nada puncak pada tuturan di atas adalah $120,1 \mathrm{~Hz}$, sedangkan nada terendahnya berada pada titik 73,2 $\mathrm{Hz}$. Julat nada pada tuturan di atas adalah $46,9 \mathrm{~Hz}$. berdasarkan identifikasi nada di atas dapat digambarkan bahwa kontur nada yang digunakan WR dalam menuturkan kalimat aku jaluk pamit kepada Dewa Indra adalah kontur nada turun atau deklinasi. Kontur tersebut dijelaskan berdasarkan terjadinya penurunan nada final dari tuturan tersebut, yakni dari mulanya nada awal berada pada titik $120,1 \mathrm{~Hz}$ turun menjadi $89,5 \mathrm{~Hz}$ pada nada final. Penggambaran kontur nada turun atau deklinasi yang digunakan WR dalam bertutur dengan Dewa Indra disajikan pada Gambar 2.

Tabel 2 Pola Prosodi TTD Requestives sub fungsi meminta 'aku jaluk pamit' WR dengan Dewa Indra

\begin{tabular}{ccccccc}
\hline Mitra tutur & Nada awal & Nada tertinggi & Nada terendah & Nada akhir & Julat nada & Durasi \\
\hline Dewa Indra & $120,1 \mathrm{~Hz}$ & $120,1 \mathrm{~Hz}$ & $73,2 \mathrm{~Hz}$ & $89,5 \mathrm{~Hz}$ & $46,9 \mathrm{~Hz}$ & $1040 \mathrm{~ms}$ \\
\hline
\end{tabular}




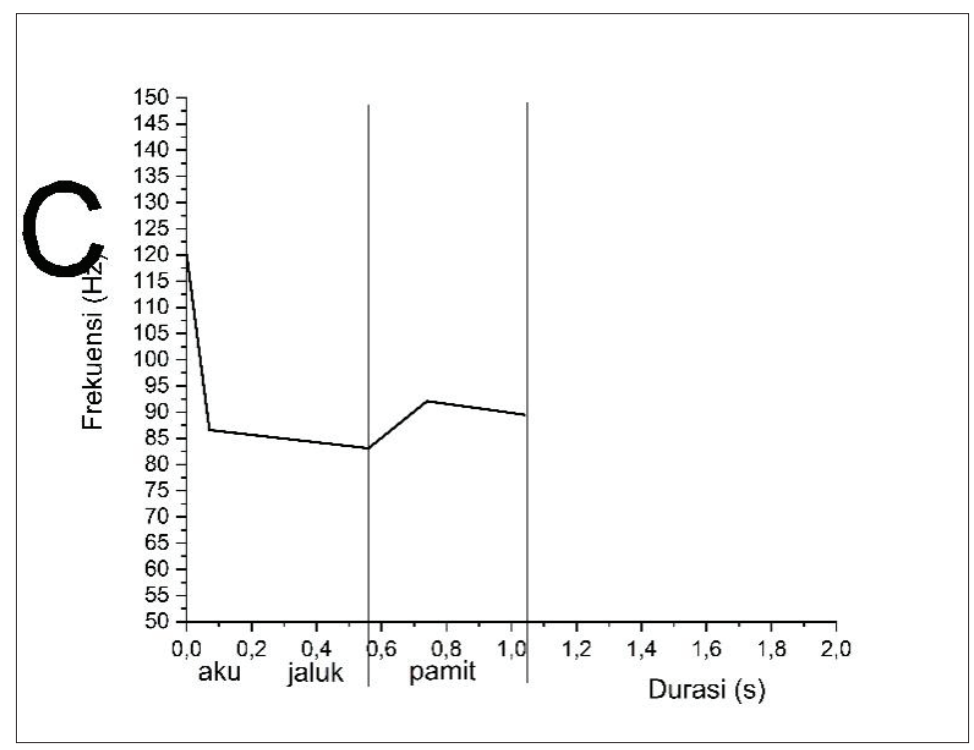

\section{Gambar 2 Kontur Nada Tuturan 'aku jaluk pamit' WR kepada Dewa Indra}

Gambar (2) menjelaskan alir nada turun digunakan WR dalam tataran subjek. Kemudian alir nada turun digunakan dalam predikat serta alir nada naik-turun pada tataran pelengkap. Secara umum tuturan aku jaluk pamit WR kepada Dewa Indra dengan konteks mitra tutur (-D, +P 'met') di atas digambarkan dengan pengggunaan kontur nada turun atau deklinasi. Adapun pada tuturan TTD WR dengan Dewa Indra di atas dituturkan WR dengan durasi $1040 \mathrm{~ms}$.

Pola Prosodi 'aku jaluk pamit' WR dengan Dewi Kunti

Tuturan TTD aku jaluk pamit juga dituturkan pada interaksi antara WR dengan ibunya, yaitu Dewi Kunti.
Menurut Tondowidjojo (2013: 162) dijelaskan bahwa Dewi Kunti adalah seorang tokoh wayang ibu yang bijaksana, memiliki dedikasi yang tinggi dalam mendidik, dan membimbing pandawa yang merupakan simbol dari generasi yang unggul. Secara konteks mitra tutur Kunti memiliki kedekatan yang intim dengan WR serta juga memiliki kuasa karena Dewi Kunti merupakan ibu kandung dari WR, hubungan tersebut disimbolkan (-D, $+\mathrm{P}$ 'met'). Interaksi antara WR dengan Kunti tersebut terjadi di Negara Ngamarta ketika WR ingin meminta restu kepada ibunya dan para saudaranya untuk melaksanakan perintah guru Durna mencari TPMS di tengah Samudera. Gambaran pola prosodi disajikan pada Tabel 3. 
Tabel 3 Pola Prosodi TTD Requestives sub fungsi meminta 'aku jaluk pamit' WR dengan Dewi Kunti

\begin{tabular}{ccccccc}
\hline Mitra tutur & Nada awal & Nada tertinggi & Nada terendah & Nada akhir & Julat nada & Durasi \\
\hline Dewi Kunti & $81,7 \mathrm{~Hz}$ & $82,6 \mathrm{~Hz}$ & $73,9 \mathrm{~Hz}$ & $75,8 \mathrm{~Hz}$ & $8,7 \mathrm{~Hz}$ & $1480 \mathrm{~ms}$ \\
\hline
\end{tabular}

Tabel (3) menunjukan tuturan aku jaluk pamit WR kepada Dewi Kunti menggunakan nada dasar $81,7 \mathrm{~Hz}$. Nada final dari kontur intonasi di atas turun menjadi $75,8 \mathrm{~Hz}$. Nada puncak pada tuturan di atas adalah $82,6 \mathrm{~Hz}$, sedangkan nada terendahnya berada pada titik 73,9 Hz. Julat nada pada tuturan di atas adalah $8,7 \mathrm{~Hz}$. Berdasarkan identifikasi nada awal dan nada akhir tersebut dapat dijelaskan bahwa WR dalam menuturkan tuturan aku jaluk pamit kepada Dewi Kunti menggunakan kontur nada turun atau deklinasi, berikut penggambaran konturnya.
Gambar (3) menjelaskan alir nada turun-naik digunakan WR dalam tataran subjek. Kemudian alir nada turun dijelaskan WR dalam tataran predikat serta alir nada naik turun pada tataran pelengkap. Secara umum kontur nada yang digambarkan WR dalam tuturan aku jaluk pamit kepada Dewi Kunti dengan konteks mitra tutur (-D, $+\mathrm{P}$ 'met') adalah kontur turun atau deklinasi. Adapun pada tuturan TTD WR dengan Dewi Kunti di atas dapat dijelaskan durasi pengucapanya, WR menunuturkan dengan durasi $1480 \mathrm{~ms}$.

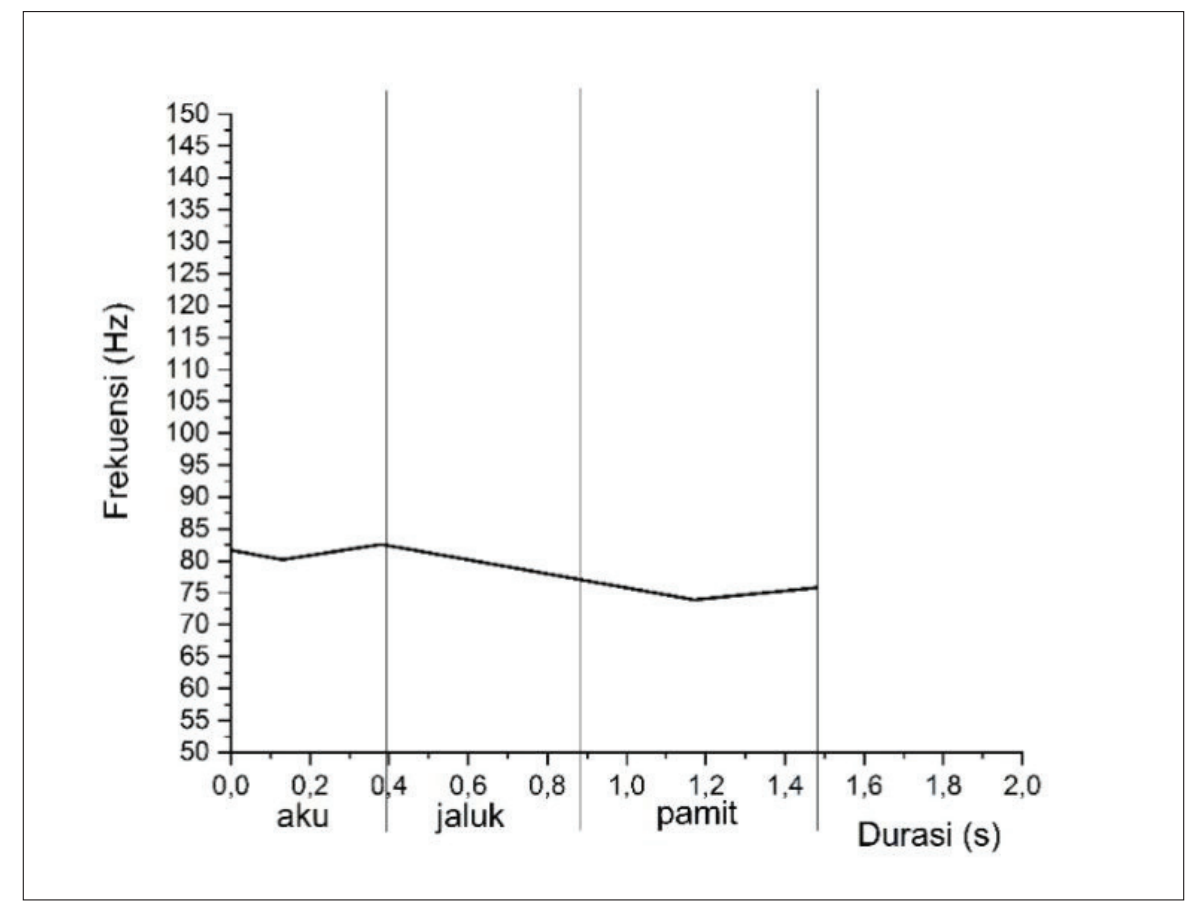

Gambar 3 Kontur Nada Tuturan 'aku jaluk pamit' WR kepada Dewi Kunti 
Pola Prosodi 'aku jaluk pamit' WR dengan Duryudana

Tuturan TTD aku jaluk pamit juga dituturkan pada awal cerita oleh WR kepada Duryudana Secara silsilah Duryudana adalah sepupu dari WR. Selain berdasarkan kedelakan tersebut, Duryudana dijelaskan juga memiliki kuasa material karena jabatan Duryudana adalah seorang Raja Ngastina. Hubungan antara WR dan Duryudana tersebut dapat disimbolkan (-D, +P 'mat'). Tuturan TTD requestives sub fungsi meminta ini diutarakan oleh WR ketika meminta restu untuk mencari TPMS. Gambaran pola prosodi disajikan pada Tabel 4 .
Tabel (4) menunjukkan pola nada pada tuturan aku jaluk pamit yang dituturkan WR kepada Duryudana. Nada dasar tuturan tersebut dapat diindentifikasikan berada pada titik 81,1 Hz. Nada final dari kontur intonasi di atas naik menjadi $84,3 \mathrm{~Hz}$. Nada puncak pada tuturan di atas adalah $84,3 \mathrm{~Hz}$, sedangkan nada terendahnya berada pada titik $72,2 \mathrm{~Hz}$. Julat nada pada tuturan di atas adalah $12,1 \mathrm{~Hz}$. Berdasarkan pola nada awal dan nada akhir yang ditunjukan tersebut, tuturan aku jaluk pamit WR kepada Duryudana dituturkan dengan kontur nada naik atau inklinasi, sebagaimana disajikan pada Gambar 4.

Tabel 4 Pola Prosodi TTD Requestives sub fungsi meminta 'aku jaluk pamit' WR dengan Duryudana

\begin{tabular}{lcccccc}
\hline Mitra tutur & Nada awal & Nada tertinggi & Nada terendah & Nada akhir & Julat nada & Durasi \\
\hline Duryudana & $81,1 \mathrm{~Hz}$ & $84,3 \mathrm{~Hz}$ & $72,2 \mathrm{~Hz}$ & $84,3 \mathrm{~Hz}$ & $12,1 \mathrm{~Hz}$ & $1000 \mathrm{~ms}$ \\
\hline
\end{tabular}

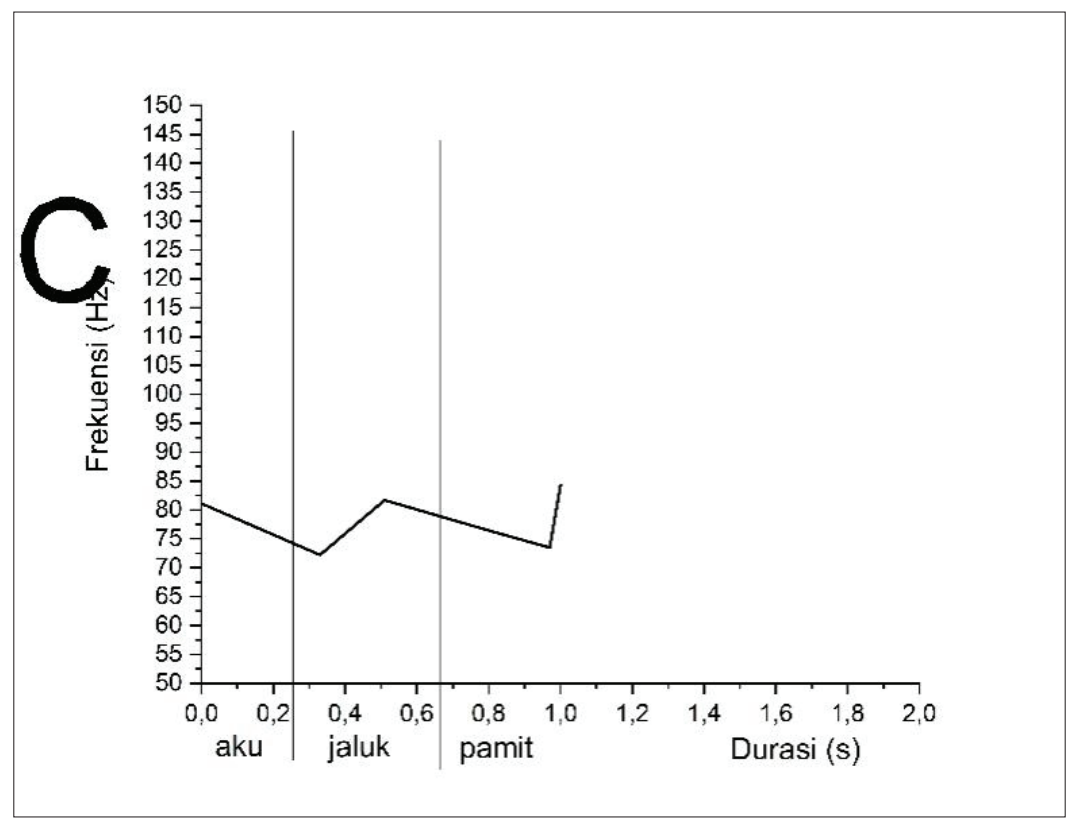

Gambar 4 Kontur Nada Tuturan 'aku jaluk pamit' WR kepada Duryudana 
Gambar (4) kontur nada tuturan aku jaluk pamit WR dengan Duryudana di atas dijelaskan menggunakan alir nada turun pada subjek. Kemudian menggunakan alir nada naik-turun pada predikat serta alir nada turun-naik pada pelengkap. Secara umum tuturan aku jaluk pamit WR kepada Duryudana dengan konteks mitra tutur (-D, +P 'mat') digambarkan dengan kontur nada naik atau inklinasi. Adapun pada tuturan TTDWR dengan Duryudana di atas dapat dijelaskan WR menuturkan tuturan tersebut dalam waktu $1000 \mathrm{~ms}$.

\section{Pola Prosodi TTD Questions subfungsi bertanya WR}

Pola prosodi kedua yang dianalisis dalam penelitian ini adalah pola prosodi TTD questions subfungsi bertanya WR dalam lakon Dewa Ruci. Kalimat tuturan yang menjadi target analisis ini adalah tuturan $a p a+S$ ?. Tuturan WR tersebut dalam lakon Dewa Ruci dituturkan WR dengan berbagai mitra tutur, yaitu Durna, Dewi Kunti, Anoman, dan Duryudana.

\section{Pola Prosodi Tuturan 'apa+S?' WR kepada Durna}

Dalam TTD questions sub fungsi bertanya dengan kalimat target 'apa+S?' WR kepada Durna dijelaskan dalam konteks pertemuan pertama WR berkunjung ke negara Ngastina dalam upaya pencarian TPMS. Pola prosodi TTD questions sub fungsi bertanya WR dengan Durna dapat ditunjukan pada Tabel 5.

Pada Tabel (5) dijelaskan pada tuturan $a p a+S$ ? dituturkan WR ke Durna memiliki nada awal $77,9 \mathrm{~Hz}$ dan nada final $68,9 \mathrm{~Hz}$. Dengan puncak nada 78,7 $\mathrm{Hz}$ dan nada terendah $63,4 \mathrm{~Hz}$. Julat nada yang ditunjukan dalam tuturan di atas adalah 15,3 Hz. Berdasarkan pola nada yang ditunjukan tersebut secara umum dapat dijelaskan bahwa tuturan $a p a+S$ ? WR ke Durna memiliki kontur nada turun atau deklinasi, sebagaimana disajikan pada Gambar 5.

Tabel 5 Pola Prosodi TTD Questions subfungsi bertanya 'apa+S?' WR dengan Durna

\begin{tabular}{ccccccc}
\hline Mitra tutur & Nada awal & Nada tertinggi & Nada terendah & Nada akhir & Julat nada & Durasi \\
\hline Durna & $77,9 \mathrm{~Hz}$ & $78,7 \mathrm{~Hz}$ & $63,4 \mathrm{~Hz}$ & $68,9 \mathrm{~Hz}$ & $15,3 \mathrm{~Hz}$ & $1130 \mathrm{~ms}$ \\
\hline
\end{tabular}

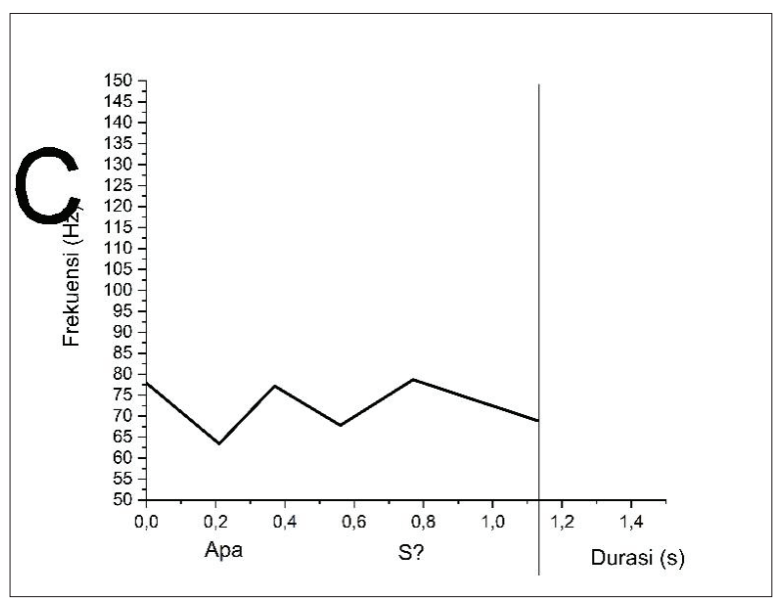

Gambar 5 Kontur Nada Tuturan 'apa+S?' WR kepada Durna 
Gambar (5) menunjukan alir nada turun-naik-turun pada penanda lingual tanya apa, kemudian alir naik-turun dalam subjek. Secara umum dapat dijelaskan bahwa kontur nada yang digunakan WR dalam tuturan apa+S? yang dituturkan ke Durna dengan konteks mitra tutur (-D, $+\mathrm{P}$ 'met') memiliki kontur nada turun atau deklinasi. Secara durasi tuturan WR dengan Durna di atas berlangsung selama $1,13 \mathrm{~s}$.

\section{Pola Prosodi Tuturan 'apa+S?' WR kepada Dewi Kunti}

Selanjutnya, pola prosodi dalam TTD questions sub fungsi bertanya pada kalimat target $a p a+S$ ? dianalisis dalam tuturan
WR dengan Dewi Kunti. Konteks cerita yang melatarbelakangi tuturan ini adalah ketika WR kembali ke negara Ngamarta untuk mencari ijin kepada ibunya untuk mencari TPMS di tengah samudera. Pola prosodi TTD questions sub fungsi bertanya WR dengan Dewi Kunti dengan kalimat target apa+S? dapat dilihat pada Tabel 6 .

Tabel (6) menjelaskan nada awal tuturan apa+S? WR yang dituturkan kepada Dewi Kunti sebesar 78,7 Hz dan nada final 75,6 Hz. Puncak nada $82,4 \mathrm{~Hz}$ dan nada terendah $72,5 \mathrm{~Hz}$. Julat nada pada tuturan di atas, yaitu sebesar $9,9 \mathrm{~Hz}$. Berdasarkan pola nada tersebut kontur nada digambarkan pada Gambar 6.

Tabel 6 Pola Prosodi TTD Questions subfungsi bertanya 'apa+S?' WR dengan Dewi Kunti

\begin{tabular}{ccccccc}
\hline Mitra tutur & Nada awal & Nada tertinggi & Nada terendah & Nada akhir & Julat nada & Durasi \\
\hline Dewi Kunti & $78,7 \mathrm{~Hz}$ & $82,4 \mathrm{~Hz}$ & $72,5 \mathrm{~Hz}$ & $75,6 \mathrm{~Hz}$ & $9,9 \mathrm{~Hz}$ & $1280 \mathrm{~ms}$ \\
\hline
\end{tabular}

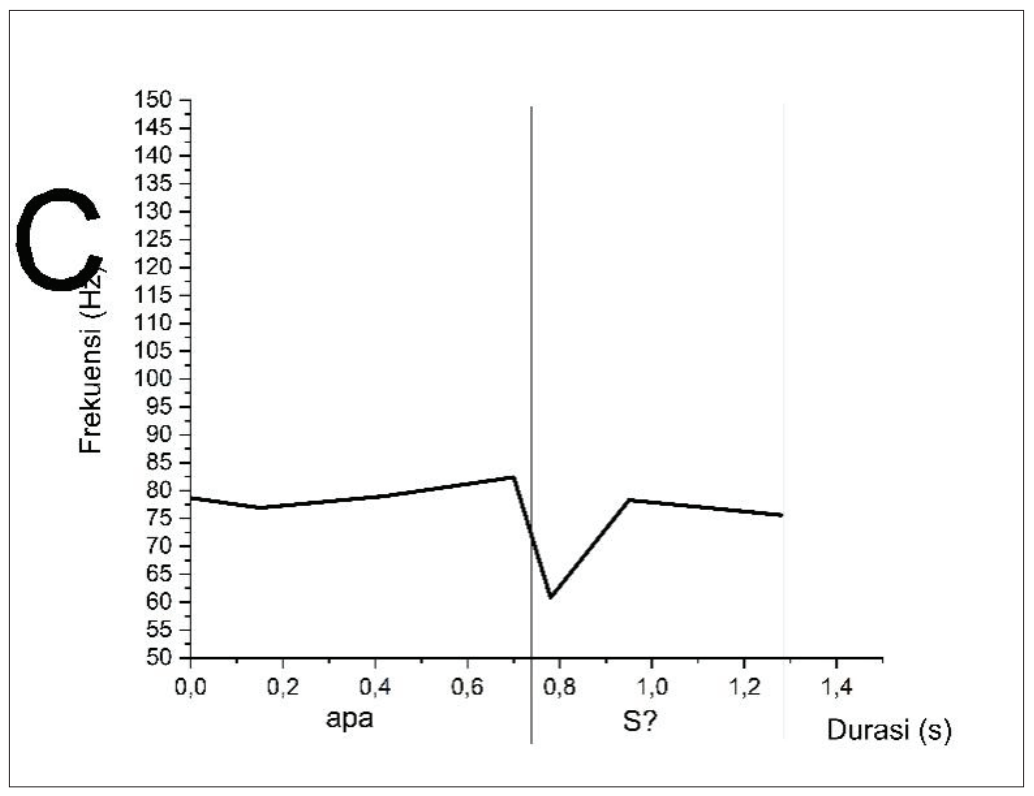

Gambar 6 Kontur Nada Tuturan 'apa+S?' WR kepada Dewi Kunti 
Gambar (6) menunjukan alir nada naik-turun pada penanda lingual tanya apa, serta turun-naik-turun pada tataran subjek. Secara umum kontur nada pada tuturan WR kepada Kunti dengan konteks mitra tutur (-D, +P 'met') menggunakan kontur turun atau deklinasi. Adapun terkait durasi tuturan WR dengan Dewi Kunti pada tuturan $a p a+S$ ? di atas berlangsung selama 1280 ms.

\section{Pola Prosodi Tuturan 'apa+S?' WR kepada Anoman}

Tuturan TTD questions sub fungsi bertanya dengan kalimat apa $+S$ ? dituturkan pada interaksi antara WR dengan Anoman. Secara konteks mitra tutur Anoman memiliki kedekatan yang intim dengan WR karena dikisahkan merupakan saudara tunggal bayu dari WR. Menurut Sujamto (1992: 58) dijelaskan WR memiliki saudara Tunggal Bayu yaitu, Anoman, Gunung Maenaka, Garuda Mahambira, Ular Naga Kuwara, Liman/ Gajah Setubanda, Kapiwara, Yaksendra YayahWReka, dan Pulasiya yang manunggal dalam tubuh Anoman sesaat sebelum perang Alengka terjadi (zaman Ramayana). Berdasarkan hal tersebut dijelaskan bahwa saudara tunggal bayu memiliki keintiman serta memiliki kuasa karena diceritakan Anoman merupakan salah satu guru dan penasehat anak-anak Pandawa. Hubungan tersebut dapat disimbolkan (-D, $+\mathrm{P}$ 'met'). Interaksi antara WR dengan Anoman tersebut terjadi di pinggir samudera ketika WR ingin mencari TPMS, namun dihadang oleh Anoman sebagaimana disajikan Tabel 7.

Pada Tabel 7 dijelaskan tuturan $a p a+S$ ? yang dituturkan kepada Anoman memiliki nada awal $71,4 \mathrm{~Hz}$ dan nada final $58,4 \mathrm{~Hz}$. Puncak nada tuturan di atas berada pada $71,4 \mathrm{~Hz}$ dan nada terendah berada pada $52,7 \mathrm{~Hz}$. Julat nada yang ditunjukan pada tuturan di atas sebesar 18,7 Hz. Berdasarkan pola nada yang ditunjukan pada tuturan $a p a+S$ ? WR dengan Anoman di atas dapat dijelaskan kontur nadanya sebagaimana disajikan pada Gambar 7.

Gambar (7) menjelaskan alir nada datar-turun pada penanda lingual apa serta alir nada naik-turun pada tataran subjek. Secara umum kontur nada tuturan apa+S? yang dituturkan WR kepada Anoman dengan konteks mitra tutur (-D, +P 'met') di atas memiliki kontur nada turun atau deklinasi. Adapun terkait durasi tuturan WR $a p a+S$ ? yang dituturkan kepada Anoman di atas berlangsung selama $1279 \mathrm{~ms}$.

Tabel 7 Pola Prosodi TTD Questions subfungsi bertanya 'apa+S?' WR dengan Anoman

\begin{tabular}{ccccccc}
\hline Mitra tutur & Nada awal & Nada tertinggi & Nada terendah & Nada akhir & Julat nada & Durasi \\
\hline Anoman & $71,4 \mathrm{~Hz}$ & $71,4 \mathrm{~Hz}$ & $52,7 \mathrm{~Hz}$ & $58,4 \mathrm{~Hz}$ & $18,7 \mathrm{~Hz}$ & $1279 \mathrm{~ms}$ \\
\hline
\end{tabular}




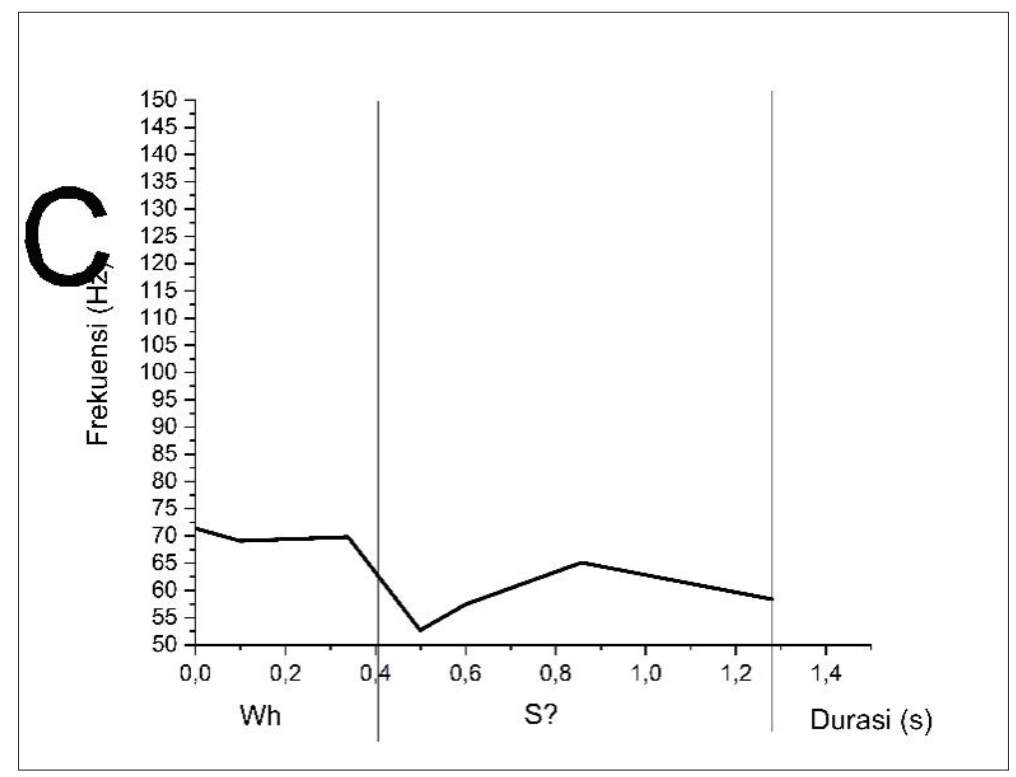

Gambar 7 Kontur Nada Tuturan 'apa+S?' WR kepada Anoman

Pola Prosodi Tuturan 'apa+S?' WR kepada Duryudana

TTD questions sub fungsi bertanya dengan kalimat target apa $+S$ ? dituturkan WR dengan Duryudana ditemukan pada konteks ketika WR berkunjung ke negara Ngastina untuk menemui guru Durna. pola prosodi tuturan tersebut dijelaskan pada Tabel 8.

Pada Tabel 8 dijelaskan pola nada tuturan $a p a+S$ ? yang dituturkan WR kepada Duryudana. Pola nada tuturan di atas dijelaskan nada awal berada pada $73,8 \mathrm{~Hz}$ dan nada final $83,7 \mathrm{~Hz}$. Puncak nada $83,7 \mathrm{~Hz}$ dan nada terendah 71,8 Hz. Julat nada pada tuturan $a p a+S$ ? dituturkan WR ke Duryudana sebesar 11,9 Hz. Berdasarkan pola nada tuturan $a p a+S$ ? yang dituturkan WR kepada Duryudana di atas dapat digambarkan kontur nada sebagaimana disajikan pada Gambar 8.

Tabel 8 Pola Prosodi TTD Questions subfungsi bertanya 'apa+S?' WR dengan Duryudana

\begin{tabular}{ccccccc}
\hline Mitra tutur & Nada awal & Nada tertinggi & Nada terendah & Nada akhir & Julat nada & Durasi \\
\hline Duryudana & $73,8 \mathrm{~Hz}$ & $83,7 \mathrm{~Hz}$ & $71,8 \mathrm{~Hz}$ & $83,7 \mathrm{~Hz}$ & $11,9 \mathrm{~Hz}$ & $936 \mathrm{~ms}$ \\
\hline
\end{tabular}




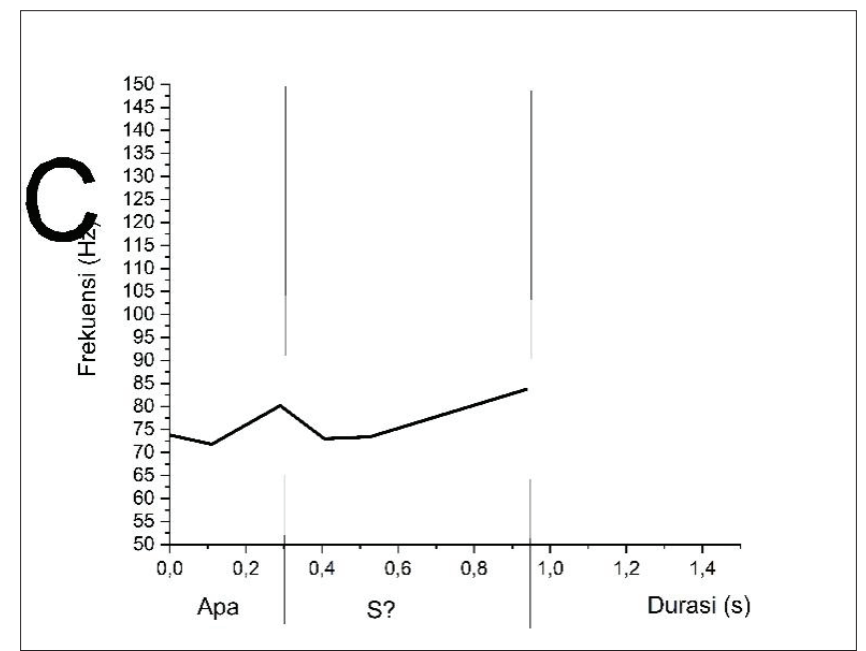

\section{Gambar 8 Kontur Nada Tuturan 'apa+S?' WR kepada Duryudana}

Pada Gambar 8 dijelaskan alir nada turun-naik pada penanda lingual apa serta alir nada turun-naik pada tataran subjek. Secara umum kontur nada yang ditunjukan pada tuturan $a p a+S$ ? WR kepada Duryudana dengan konteks mitra tutur (-D, $+\mathrm{P}$ 'met') tersebut dijelaskan menggunakan kontur nada naik atau inklinasi. Secara durasi tuturan WR dengan Duryudana di atas berlangsung selama $936 \mathrm{~ms}$.

\section{Pembahasan}

Berdasarkan hasil analisis di atas dapat dijelaskan bahwa terdapat tiga pola prosodi yang digunakan WR. Adapun pola yang digambarkan WR dalam TTDnya dengan berbagai tokoh dalam lakon Dewa Ruci disajikan pada Gambar 9 dan 10.

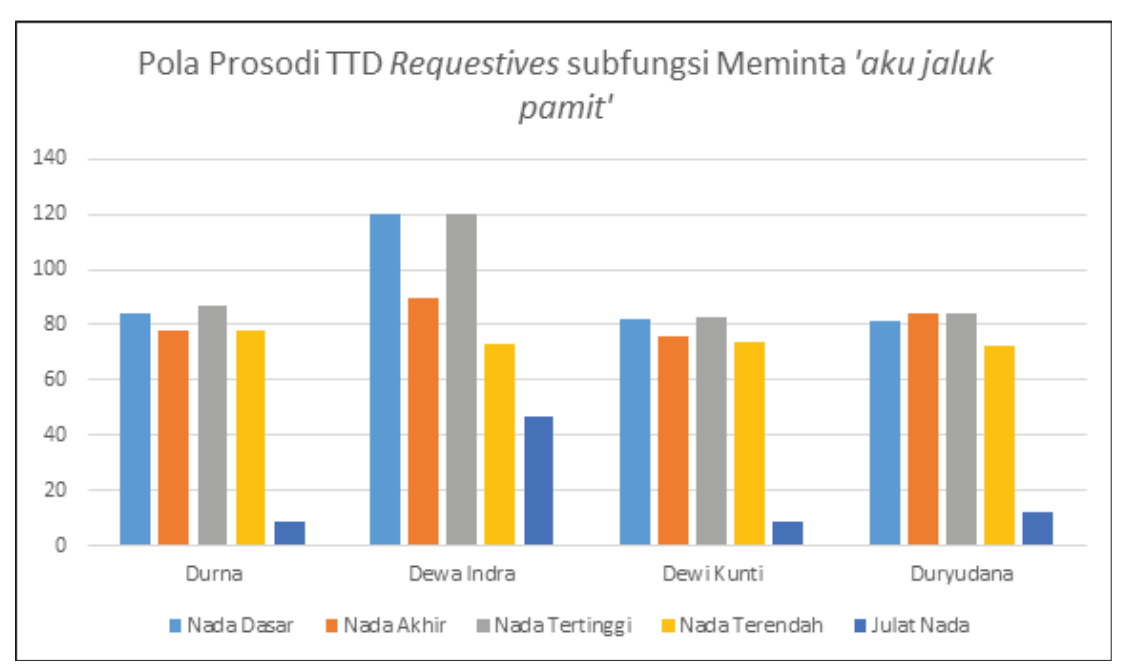

Gambar 9 Pola Nada TTD Requestives subfungsi Meminta 'aku jaluk pamit' 


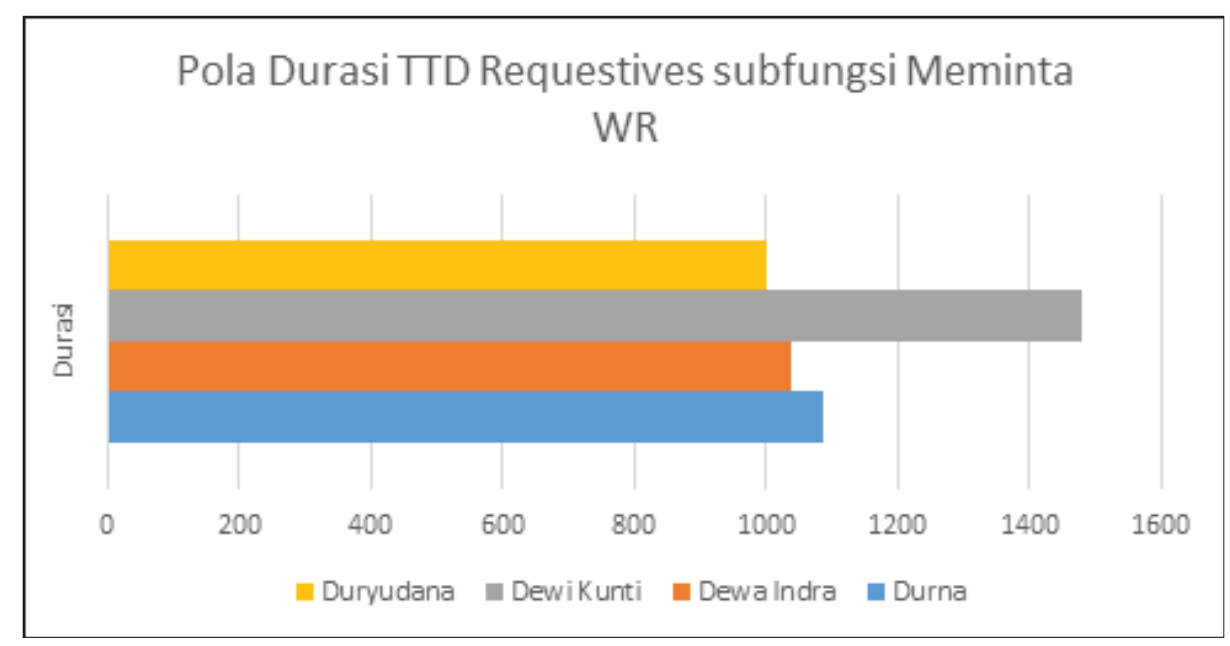

\section{Gambar 10 Pola Durasi TTD Requestives subfungsi Meminta 'aku jaluk pamit' WR}

Berdasarkan gambar (9) dan (10) dapat diperoleh gambaran bahwa masing-masing tuturan yang dituturkan kepada berbagai mitra tutur memiliki pola prosodi yang berbeda. Hal ini dapat ditinjau di dalam gambar di atas yang menunjukan nada awal, nada akhir, nada tertinggi, nada terendah, julat nada, dan durasi yang dituturkan WR kepada setiap mitra tuturnya.

Berdasarkan gambar (9) dan (10) dapat dibahas pola tuturan TTD aku jaluk pamit WR kepada mitra tuturnya, pertama, tuturan WR dengan Durna dijelaskan WR mengutarakan tuturan aku jaluk pamit dengan kontur nada turun atau deklinasi hal tersebut dijelaskan dengan nada dasar $84,4 \mathrm{~Hz}$ dan turun pada nada akhir yang berada pada $78 \mathrm{~Hz}$. Julat nada tuturan aku jaluk pamit yang dituturkan WR kepada Durna yaitu 9 $\mathrm{Hz}$. selanjutnya durasi dalam aku jaluk pamit yang dituturkan WR kepada Durna dianalisis selama $1088 \mathrm{~ms}$.

Kedua, pola prosodi tuturan aku jaluk pamit yang dituturkan WR kepada Dewa
Indra dijelaskan WR menggunakan kontur nada turun atau deklinasi. Hal tersebut dijelaskan dengan nada awal yang berada pada $120,1 \mathrm{~Hz}$ dan nada akhir berada pada titik $89,5 \mathrm{~Hz}$. Julat nada pada tuturan aku jaluk pamit yang dituturkan WR kepada Dewa Indra sebesar $46,9 \mathrm{~Hz}$. selanjutnya durasi yang digunakan WR dalam menuturkan tuturan tersebut kepada Dewa Indra adalah selama $1040 \mathrm{~ms}$.

Ketiga, pola prosodi tuturan aku jaluk pamit yang dituturkan WR kepada Dewi Kunti dijelaskan WR menggunakan kontur nada turun atau deklinasi. Hal tersebut dijelaskan dengan nada awal yang berada pada $81,7 \mathrm{~Hz}$ dan nada akhir berada pada titik $75,8 \mathrm{~Hz}$. Julat nada pada tuturan aku jaluk pamit yang dituturkan WR kepada Dewi Kunti sebesar $8,7 \mathrm{~Hz}$. selanjutnya durasi yang digunakan WR dalam menuturkan tuturan tersebut kepada Dewi Kunti adalah selama $1480 \mathrm{~ms}$.

Terakhir, pola prosodi tuturan aku jaluk pamit yang dituturkan WR kepada 
Duryudana dijelaskan WR menggunakan kontur nada naik atau inklinasi. Hal tersebut dijelaskan dengan nada awal yang berada pada $81,1 \mathrm{~Hz}$ dan nada akhir berada pada titik $84,3 \mathrm{~Hz}$. Julat nada pada tuturan aku jaluk pamit yang dituturkan WR kepada Duryudana sebesar 12,1 Hz. Kemudian, durasi yang digunakan WR dalam menuturkan tuturan tersebut kepada Duryudana adalah selama $1000 \mathrm{~ms}$.

Selanjutnya, pembahasan kedua adalah pola prosodi TTD questions subfungsi bertanya 'apa $+S$ ?' WR dengan mitra tuturnya dalam lakon Dewa Ruci dijelaskan dalam Gamabr 11.

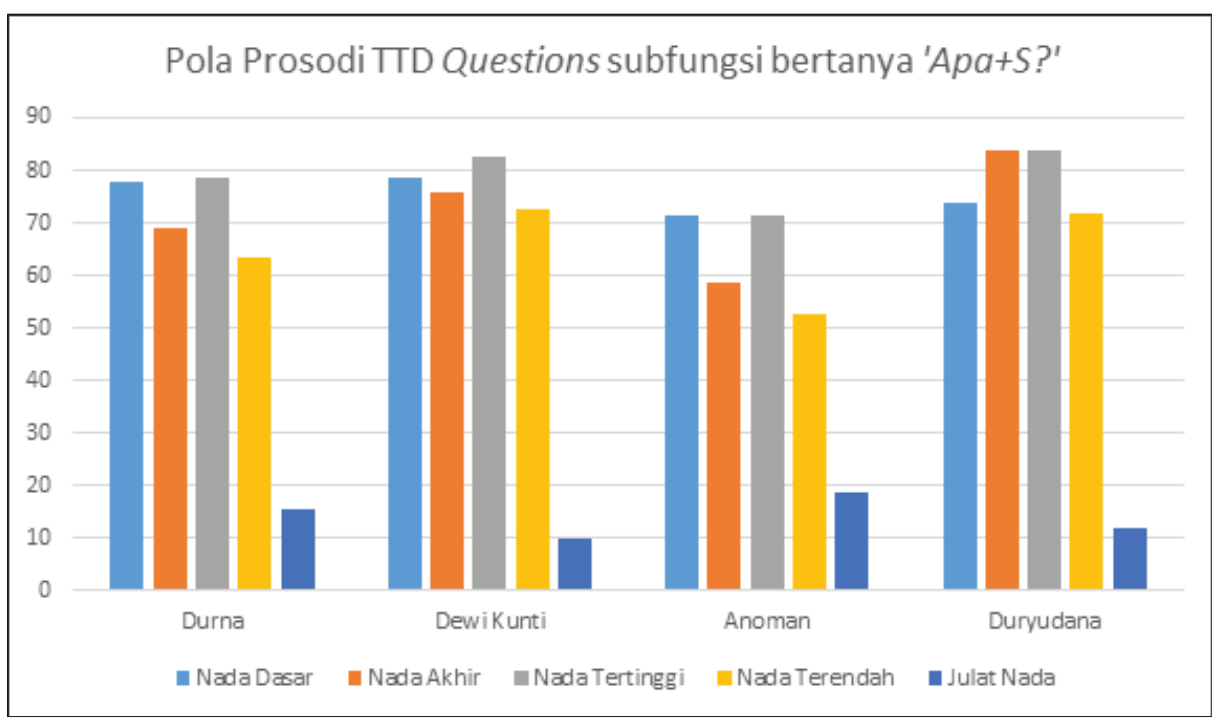

Gambar 11 Pola Prosodi TTD Questions subfungsi bertanya ‘Apa+S?' WR

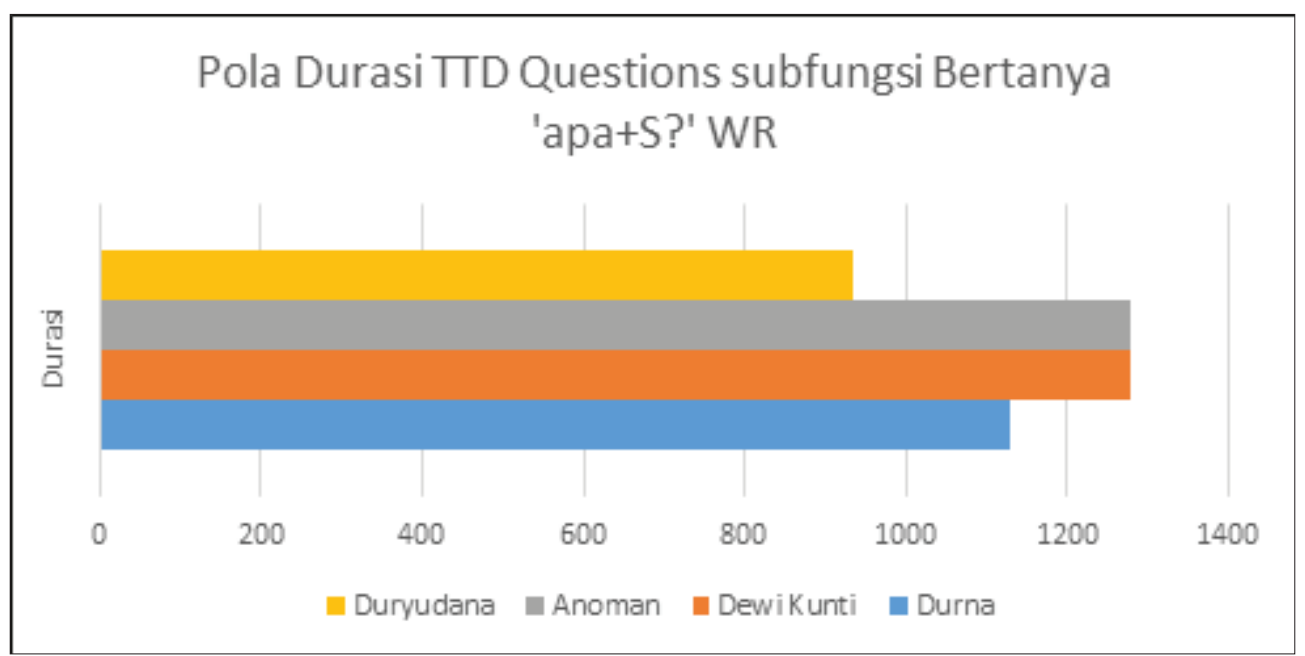

Gambar 12 Pola Durasi TTD Questions subfungsi Bertanya 'apa+S?' WR 
Gambar (11) dan (12) di atas menjelaskan gambaran bahwa masingmasing tuturan yang dituturkan kepada berbagai mitra tutur memiliki pola prosodi yang berbeda. Hal ini dapat ditinjau di dalam gambar di atas yang menunjukan nada awal, nada akhir, nada tertinggi, nada terendah, julat nada, dan durasi yang dituturkan WR kepada setiap mitra tuturnya.

Gambar (11) dan (12) juga menjalaskan pola prosodi tuturan apa $+S$ yang dituturkan WR kepada Durna dijelaskan WR menggunakan kontur turun atau deklinasi. Hal tersebut dijelaskan dengan nada awal yang berada pada $77,9 \mathrm{~Hz}$ dan nada akhir berada pada titik $68,9 \mathrm{~Hz}$. Julat nada pada tuturan $a p a+S$ yang dituturkan WR kepada Durna sebesar 15,3 Hz. Kemudian, durasi yang digunakan WR dalam menuturkan tuturan tersebut kepada Durna adalah selama $1130 \mathrm{~ms}$.

$K e d u a$, pola prosodi tuturan $a p a+S$ yang dituturkan WR kepada Dewi Kunti dijelaskan WR menggunakan kontur turun atau deklinasi. Hal tersebut dijelaskan dengan nada awal yang berada pada $78,7 \mathrm{~Hz}$ dan nada akhir berada pada titik 75,6 Hz. Julat nada pada tuturan $a p a+S$ yang dituturkan WR kepada Dewi Kunti sebesar 9,9 Hz. Kemudian, durasi yang digunakan WR dalam menuturkan tuturan tersebut kepada Dewi Kunti adalah selama $1280 \mathrm{~ms}$.

Ketiga, pola prosodi tuturan $a p a+S$ yang dituturkan WR kepada Anoman dijelaskan WR menggunakan kontur turun atau deklinasi. Hal tersebut dijelaskan dengan nada awal yang berada pada $71,4 \mathrm{~Hz}$ dan nada akhir berada pada titik $58,4 \mathrm{~Hz}$. Julat nada pada tuturan $a p a+S$ yang dituturkan WR kepada Anoman sebesar 18,7 Hz. Kemudian, durasi yang digunakan WR dalam menuturkan tuturan tersebut kepada Anoman adalah selama 1279 ms.

Terakhir, pola prosodi tuturan apa $+S$ yang dituturkan WR kepada Duryudana dijelaskan WR menggunakan kontur naik atau inklinasi. Hal tersebut dijelaskan dengan nada awal yang berada pada $73,8 \mathrm{~Hz}$ dan nada akhir berada pada titik $83,7 \mathrm{~Hz}$. Julat nada pada tuturan $a p a+S$ yang dituturkan WR kepada Duryudana sebesar $11,9 \mathrm{~Hz}$ Kemudian, durasi yang digunakan WR dalam menuturkan tuturan tersebut kepada Duryudana adalah selama $936 \mathrm{~ms}$.

Hal menarik dari analisis prosodi yang dipaparkan berdasarkan diagaram di atas adalah 1) kontur nada, 2) julat nada, dan 3) durasi. Ketiga aspek tersebut dirangkum dalam Tabel 9.

Tabel 9 Pola Prosodi TTD Requestives subfungsi Meminta 'aku jaluk pamit' WR

\begin{tabular}{lllcc}
\hline \multicolumn{1}{c}{ Mitra Tutur } & \multicolumn{1}{c}{ Konteks Mitra Tutur } & \multicolumn{1}{c}{ Alir Nada } & Julat nada & Durasi \\
\hline Durna & $(-\mathrm{D},+\mathrm{P}$ 'met') & Turun atau deklinasi & $9 \mathrm{~Hz}$ & $1080 \mathrm{~ms}$ \\
Dewa Indra & $(+\mathrm{D},+\mathrm{P}$ 'met') & Turun atau deklinasi & $46,9 \mathrm{~Hz}$ & $1040 \mathrm{~ms}$ \\
Dewi Kunti & $(-\mathrm{D},+\mathrm{P}$ 'met') & Turun atau deklinasi & $8,7 \mathrm{~Hz}$ & $1480 \mathrm{~ms}$ \\
Duryudana & $(-\mathrm{D},+\mathrm{P}$ 'mat') & Naik atau inklinasi & $12,1 \mathrm{~Hz}$ & $1000 \mathrm{~ms}$ \\
\hline
\end{tabular}


Tabel 10 Pola Prosodi TTD Questions subfungsi Bertanya 'apa+S?' WR

\begin{tabular}{lllll}
\hline Mitra Tutur & Konteks Mitra Tutur & Alir Nada & Julat nada & Durasi \\
\hline Durna & $(-\mathrm{D},+\mathrm{P}$ 'met') & Turun atau deklinasi & $15,3 \mathrm{~Hz}$ & $1130 \mathrm{~ms}$ \\
Dewi Kunti & $(-\mathrm{D},+\mathrm{P}$ 'met') & Turun atau deklinasi & $9,9 \mathrm{~Hz}$ & $1280 \mathrm{~ms}$ \\
Anoman & $(-\mathrm{D},+\mathrm{P}$ 'met') & Turun atau deklinasi & $18,7 \mathrm{~Hz}$ & $1279 \mathrm{~ms}$ \\
Duryudana & $(-\mathrm{D},+\mathrm{P}$ 'mat') & Naik atau inklinasi & $11,9 \mathrm{~Hz}$ & $936 \mathrm{~ms}$ \\
\hline
\end{tabular}

Berdasarkan kedua tabel (9) dan (10) dapat dijelaskan bahwa WR memiliki pola prosodi yang teratur terkait tuturanya dengan mitra tutur. Pola prosodi WR tersebut memiliki keteraturan sesuai konteks mitra tutur yang dihadapi. Adapun pola prosodi dapat dijelaskan dalam tiga klasifikasi konteks mitra tutur, yaitu ( $+\mathrm{D},+\mathrm{P}$ 'met'), (-D, $+\mathrm{P}$ 'met), dan $(+\mathrm{D},+\mathrm{P}$ 'mat $)$.

\section{Pola Prosodi WR dengan Konteks Mitra tutur $(+D,+P$ 'met').}

Pola prosodi pertama ditunjukan WR ketika bertutur dengan konteks mitra tutur (+D, + P 'met'). Mitra tutur yang dimaksud dalam konteks ini adalah Dewa Indra. WR mengakui bahwa Dewa Indra memiliki derajat yang lebih tinggi daripada manusia biasa. Menurut Musbikin (2010: 131) menjelaskan bahawa Dewa Indra merupakan pimpinan Dewa yang mengatur para dewa lain atas titah bethara Guru. Dewa Indra dijelaskan juga memiliki kuasa yang besar atas kehidupan titah manusia. Berdasarkan kuasa metafisika tersebut pola prosodi dalam menuturkan TTD requestives subfungsi meminta dengan kalimat target 'aku jaluk pamit' WR kepada Dewa Indra adalah kontur nada turun atau deklinasi, julat nada lebar, dan durasi yang panjang.

Kontur nada turun atau deklinasi serta durasi yang panjang menjadi pola tuturan 'aku jaluk pamit' WR dengan Dewa Indra. Rahardi (1999: 5) dan Rahyono (2009:15) menjelaskan dengan penggunaan kontur nada turun atau deklinasi serta durasi yang panjang dalam tuturan maka tuturan tersebut memiliki daya ancaman muka yang rendah serta memiliki kadar kesantunan yang tinggi.

Selanjutnya penggunaan julat nada pada tuturan 'aku jaluk pamit' WR dengan Dewa Indra menunjukan julat nada paling lebar. Julat nada lebar tersebut menunjukan tuturan 'aku jaluk pamit' yang dituturkan WR kepada Dewa Indra dituturkan secara melodis. Navarro \& Nebot (2014: 17) menjelaskan tuturan dengan julat nada yang lebar dapat menyatakan ekpresi penutur dengan jelas. Adapaun dengan pengungkapan secara jelas tersebut dapat berimplikasi pada upaya menjaga kesantunan yang lebih kepada mitra tutur.

\section{Pola Prosodi WR dengan Konteks Mitra tutur ( $-D,+P$ 'met')}

Pola kedua dapat diidentifikasi ketika WR melakukan interaksi dengan konteks mitra tutur ( $-\mathrm{D},+\mathrm{P}$ 'met'). Mitra tutur yang dimaksud dalam hal ini adalah guru Durna, Dewi Kunti, dan Anoman. WR dalam lakon Dewa Ruci memiliki kedekatan yang intim terhadap ketiga 
tokoh tersebut. Secara konteks mitra tutur guru Durna adalah guru WR dari kecil sampai dewasa. Durna sangat berjasa bagi sisi keilmuan WR dari segi ilmu peperangan, ilmu persenjataan sampai ilmu terkait kehidupan. Hal tersebut ditegaskan oleh Isnaniah (2010) yang menjelaskan bahwa Durna merupakan Guru sejati dari WR.

Selanjutnya, salah satu tokoh yang memiliki konteks mitra tutur sama dengan Durna adalah Dewi Kunti. Dewi Kunti merupakan ibu dari WR. WR memiliki kedekatan yang intim dengan Dewi Kunti dengan hubungan anak dan ibu. Konteks kuasa metafisika dijelaskan karena Dewi Kunti merupakan sosok yang berjasa dalam membentuk dirinya menjadi kesatriya yang unggul. Menurut Tondowidjojo (2013: 162) dijelaskan bahwa Dewi Kunti adalah seorang tokoh wayang ibu yang bijaksana, memiliki dedikasi yang tinggi dalam mendidik, dan membimbing pandawa yang merupakan simbol dari generasi yang unggul.

Terakhir, tokoh yang memiliki konteks mitra tutur yang sama adalah Anoman. Menurut Sujamto (1992: 58) dijelaskan WR memiliki saudara Tunggal Bayu yaitu, Anoman, Gunung Maenaka, Garuda Mahambira, Ular Naga Kuwara, Liman/ Gajah Setubanda, Kapiwara, Yaksendra YayahWReka, dan Pulasiya yang manunggal dalam tubuh Anoman sesaat sebelum perang Alengka terjadi (zaman Ramayana). Berdasarkan hal tersebut dijelaskan bahwa saudara tunggal bayu memiliki keintiman serta memiliki kuasa karena diceritakan Anoman merupakan salah satu guru dan penasehat anak-anak Pandawa yang paling berpengaruh atas kejayaan Pandawa khususnya pada pembentukan kesaktian dan kepribadian WR.

Berdasarkan konsep mitra tutur, yaitu kedekatan dan kuasa metafisika (-D, $+\mathrm{P}$ 'met') tersebut pola prosodi dalam menuturkan TTD requestives subfungsi meminta dengan kalimat target 'aku jaluk pamit' serta TTD questions subfungsi bertanya dengan kalimat target 'apa+S?' WR kepada Durna, Dewi Kunti, dan Anoman adalah kontur nada turun atau deklinasi, durasi panjang, dan julat nada sempit.

Kontur nada turun atau deklinasi serta durasi yang panjang menjadi pola tuturan 'aku jaluk pamit' dan tuturan 'apa+S?' WR dengan Durna, Dewi Kunti, dan Anoman. Rahardi (1999: 5) dan Rahyono (2009:15) menjelaskan dengan penggunaan kontur nada turun atau deklinasi serta durasi yang panjang dalam tuturan maka tuturan tersebut memiliki daya ancaman muka yang rendah serta memiliki kadar kesantunan yang tinggi.

Selanjutnya penggunaan julat nada pada tuturan 'aku jaluk pamit' dan tuturan 'apa+S?' WR dengan Durna, Dewi Kunti, dan Durna menunjukan julat nada sempit. Julat nada lebar tersebut menunjukan tuturan 'aku jaluk pamit' yang dituturkan WR kepada Durna, Dewi Kunti, dan Durna dituturkan secara monoton. Hal tersebut sesuai dengan gaya berbicara WR dalam pewayangan. Poedjoesoedarmo (1986: 68) menjelaskan bahwa pengkarakteran WR dalam pewayangan ditunjukan dari segi penyuaraan, dalam bertutur WR menggunakan intonasi yang datar dan nada yang rendah laki-laki. 
Pola Prosodi WR dengan Konteks Mitra tutur ( $+D,-P$ ' $m e t$ ')

Pola terakhir yang dapat diindentifikasi dari tuturan WR adalah tuturan WR dengan Duryudana. pola prosodi ini dilakukan WR dengan konteks mitra tutur memiliki kedekatan dengan penutur serta memiliki kuasa materil terhadap penutur atau disimbolkan (-D, +P 'mat'). Secara konteks mitra tutur Duryudana adalah sepupu dari WR dan juga merupakan raja dari Ngastina. Secara detil Widyawati (2009: 89) menjelaskan bahwa kuasa Duryudana terhadap WR terbangun karena Duryudana adalah raja di Kerajaan Kuru dengan pusat pemerintahanjnya di Hastinapura.

Berdasarkan konsep mitra tutur, yaitu kedekatan dan kuasa materil $(-\mathrm{D},+\mathrm{P}$ 'mat') tersebut pola prosodi dalam menuturkan TTD requestives subfungsi meminta dengan kalimat target 'aku jaluk pamit' serta TTD questions subfungsi bertanya dengan kalimat target 'apa+S?' WR kepada Duryudana adalah kontur nada naik atau inklinasi, durasi pendek, dan julat nada sempit.

Kontur nada naik atau inklinasi serta durasi yang pendek menjadi pola tuturan 'aku jaluk pamit' dan tuturan 'apa+S?'WR dengan Durna, Dewi Kunti, dan Anoman. Rahardi (1999: 5) dan Rahyono (2009:15) menjelaskan dengan penggunaan kontur nada naik atau inklinasi serta durasi yang pendek memiliki nilai kesantunan yang rendah jika dibanding kontur nada turun atau deklinasi serta durasi yang panjang. Hal tersebut diindikasikan bahwa WR kurang menjaga kesantunan terhadap Duryudana.
Selanjutnya penggunaan julat nada pada tuturan 'aku jaluk pamit' dan tuturan 'apa+S?' WR dengan Duryudana menunjukan julat nada sempit. Julat nada lebar tersebut menunjukan tuturan 'aku jaluk pamit' yang dituturkan WR kepada Durna, Dewi Kunti, dan Durna dituturkan secara monoton. Hal tersebut sesuai dengan gaya berbicara WR dalam pewayangan. Poedjoesoedarmo (1986: 68) menjelaskan bahwa pengkarakteran WR dalam pewayangan ditunjukan dari segi penyuaraan, dalam bertutur WR menggunakan intonasi yang datar dan nada yang rendah laki-laki.

\section{SIMPULAN}

Berdasarkan pembahasan pola prosodi terkait TTD requestives subfungsi meminta dengan kalimat target 'aku jaluk pamit' dan TTD questions subfungsi bertanya dengan kalimat target 'apa+S?' dapat dijelaskan terdapat tiga pola. Adapun pola yang pertama adalah pola prosodi yang digunakan WR ketikda bertutur dengan konteks mitra tutur $(+\mathrm{D},+\mathrm{P}$ 'met') dalam tuturanya WR menggunakan pola prosodi kontur nada turun atau deklinasi, julat nada tinggi (melodis), dan durasi panjang. Kedua, pola prosodi WR ketika bertutur dengan konteks mitra tutur (-D, +P 'met') menggunakan pola prosodi kontur nada turun atau deklinasi, julat nada kecil (monoton), dan durasi panjang. Ketiga, pola prosodi WR ketika bertutur dengan konteks mitra tutur $(+\mathrm{D},+\mathrm{P}$ 'mat') menggunakan pola prosodi kontur nada naik atau inklinasi, julat nada kecil (monoton), dan durasi pendek. 


\section{UCAPAN TERIMA KASIH}

Ucapan terima kasih disampaikan kepada reviewer dan teman sejawat yang telah memberi masukan dan saran untuk perbaikan artikel ini. Harapannya, tulisan ini dapat memberikan manfaat bagi perkembangan khasanah ilmu linguistik yang berfokus pada kajian budaya. Selain itu, semoga artikel ini dapat memberikan pemahaman terhadap pengkarakteran wayang oleh dalang dengan sudut pandang yang berbeda.

\section{DAFTAR PUSTAKA}

Brown, \& Gilman. (1960). The Pronouns of Power and Solidarity. MIT Press.

Brown, P., \& Levinson, S. C. (1983). Politeness Some Universals in Language Usage. Cambridge: Cambridge University Press.

Chaer, A. (2009). Fonologi Bahasa Indonesia. Jakarta: Rineka Cipta.

Culpaper, J. (2003). (Im)politeness: Prosody and Gesture. Journal of Pragmatics, 35.

Culpeper, J. (2011a). 'It's not what you said, it's how you said it!': Prosody and impoliteness. In Discursive Approaches to Politeness. Berlin: De Gruyter Mouton.

Culpeper, J. (2011b). It's not what you said, it"s how you said it!"e: Prosody and impoliteness. Linguistic Politeness Research Group (Eds.) Discursive Approaches to Politeness.

Gussenhoven, C., Hart, J. 't, Collier, R., Cohen, A., \& Collier, R. (1992). A Perceptual Study of Intonation. An Experimental-Phonetic Approach to Speech Melody. Language, 68(3), $610 . \quad$ https://doi. org/10.2307/415797
Heriyawati, D. F., Siba, S. Y., \& Sulistyo, T. (2019). Lecturers' Politeness Strategies in Efl Classroom with Multicultural Background. Litera, 18. https://doi.org/https://doi. org/10.21831/1tr.v18i3.26494

Huang, Y. (2007). Pragmatics. Oxford: Oxford University Press.

Isnaniah, S. (2010). Dewa Ruci: Sebuah Alternatif Sistem Pendidikan. LiNGUA, 5. https://doi.org/ https://doi.org/10.18860/ling. v5i1.612

Lisbijanto, H. (2013). Wayang. Yogyakarta: Graha Ilmu.

Manaf, N. A. (2011). Kesopanan Tindak Tutur Menyuruh dalam Bahasa Indonesia. Litera, 10. https://doi. org/https://doi.org/10.1016/j. pragma.2010.09.015

Musbikin, I. (2010). Serat Dewa Ruci. Yogyakarta: Diva Press.

Nadeu, M. (2014). Pitch range, gestural information, and perceived politeness in Catalan. Journal of Pragmatics, 43.

Nanda. (2010). Wayang. Yogyakarta: Bintang cemerlang.

Navarro, A. H., \& Nebot, A. C. (2014). On the Importance of the Prosodic Component in the Expression of Linguistic im/Politeness. Journal of Politeness Research, 10. https://doi. org/DOI 10.1515/pr-2014-0002

Petersen, R., \& Petersen, R. (2001). Lakon Karangan: The Legacy of $\mathrm{Ki}$ Nartosabdho in Banyumas, Central Java Lakon Karangan: The Legacy of Ki Nartosabdho in Banyumas, Central Java. 18(1), 105-112. https://doi. org/10.1353/atj.2001.0007 
Poedjoesoedarmo. (1986). Ragam Panggung dalam Bahasa Jawa. Jakarta: PusatPembinaandanPengembangan Bahasa.

Rahardi, K. (1999a). Imperatif dalam Bahasa Indonesia: PenandaPenanda Kesantunan Linguistik. Humaniora.

Rahardi, K. (1999b). Imperatif Dalam Bahasa Indonesia Penanda-Penanda Kesantunan Linguistiknya. Humaniora.

Rahyono, F. X. (2009). The Politeness Prosody of the Javanese Directive Speech. Wacana, 11, 258-278.

Sena Wangi. (1999). Ensiklopedia Wayang Indonesia. Jakarta: PT Sakanindo Printama.

Soetarno. (1994). Ensiklopedia Wayang. Semarang: Dahara Prize.

Sudaryanto. (1993). Metode Aneka Teknik Analisis Bahasa Pengantar Penelitian
Wahana Kebudayaan Secara Linguistis. Yogyakarta: Duta Wacana University Press.

Sugiyono. (2007). Prosodic Markers of Statement-Question Contrast in Kutai Malay. Leiden: LOT.

Sujamto. (1992). Wayang dan Budaya Jawa. Semarang: Dahara Prize.

Sumari. (2016). Almanak Wayang Indonesia. Jakarta: Prenadamedia.

Sutardjo, I. (2010). Keindahan Bahasa Pedalangan. Solo: FSSR Publishing.

Tondowidjojo, J. (2013). Enneagram Dalam Wayang Purwa. Jakarta: Gramedia Pustaka Utama.

Widodo, W. (2017). Hal yang Rumpang dan Timpang dalam Kebijakan Perencanaan Bahasa Jawa. Linguistik Indonesia, Vol ke 35, :hal 34-52.

Widyawati, W. (2009). Ensiklopedia Wayang. Yogyakarta: Pura Pustaka. 